\title{
Redução do nível de contaminação por Salmonella Enteritidis em frangos de corte*
}

\author{
LUIZ ANTONIO FACCENDA DE AVILA
}

\author{
Vladimir Pinheiro do Nascimento (Orientador - UFRGS)
}

Banca: Ricardo Alfredo Soncini (SADIA), Sérgio Luiz Vieira (UFRGS), Hamilton Luiz de Souza Moraes (UFRGS).

\begin{abstract}
As salmonelas causadoras do Paratifo Aviário, principalmente a Salmonella Enteritidis (SE), têm estado entre as principais causas de toxinfecção alimentar em humanos, causando grandes prejuízos ao setor produtivo. A busca de uma medida única e definitiva para o controle do Paratifo Aviário tem levado a frustração dos esforços empregados, em função das características dos agentes e da infecção provocada. Portanto, ganha força a estratégia de utilizar-se um conjunto de medidas que objetivem a redução gradativa da pressão infectiva em um sistema de produção, levando à melhora crescente do grau de contaminação dos produtos disponibilizados aos consumidores. $\mathrm{O}$ objetivo desta tese é fornecer à indústria avícola um conjunto de meios práticos para o controle do Paratifo Aviário e, conseqüentemente, para a produção de alimentos mais seguros ao consumo humano. Para tanto, foram conduzidos quatro estudos, sendo que três estudos foram dedicados ao aumento de resistência das aves à infecção por SE e o quarto estuda a redução do número desta bactéria na ave no período de pré-abate. Em um experimento avaliou-se a imunização das aves com uma bacterina de SE, objetivando o aumento da resistência à infecção por SE em matrizes de frango de corte. Três semanas após o início do desafio, não foram detectadas diferenças entre os grupos testados nos números de SE recuperadas do ceco e no número de cecos e fígados infectados por este agente. Esta conclusão, embora verdadeira para as condições experimentais usadas, necessita de experimentações adicionais em condições de criação tradicional para ser referendada. A Vacinação Maternal e o uso de Probiótico, como medidas para aumentar a resistência inicial de pintos de corte, foram estudados em 3 experimentos. O uso de Probiótico causou uma redução no número de ufc de SE nos cecos de até $1,45 \log _{10}$. A maior redução, ocorrida no Experimento III, demonstra a importância da antecipação do uso do Probiótico em relação ao início do desafio. Não se verificou nenhum efeito da Vacinação Maternal no número de cecos positivos ou no número de ufc de SE no ceco. Em quatro experimentos foram investigados os efeitos da pulverização da cepa 9R de Salmonella Gallinarum (SG-9R) em pintos de corte de um dia de idade sobre a infecção provocada artificialmente por SE. A aplicação da SG-9R em pintos de um dia apresenta potencial para auxiliar no controle da infecção por SE. Em que pese essa conclusão, estudos adicionais são necessários para verificar a magnitude da efetividade desta medida, bem como determinar a probabilidade de reversão de patogenicidade da SG-9R. Em três experimentos estudou-se a administração de água acidificada no pré abate de frangos de corte. Esta administração nas 24 horas que precedem o carregamento para o abate levou a uma redução de $99 \%$ no número de salmonelas no inglúvio dos frangos. Esta medida não é ideal, já que não evita a doença nas aves e, também, não garante a produção de alimentos integralmente livre de Salmonella. Porém, pode tornar-se uma importante ferramenta para redução da contaminação no abate dos lotes de frangos positivos para enfermidade.
\end{abstract}

Descritores: frangos de corte, Salmonella Enteritidis, redução de contaminação, Paratifo Aviário. 


\title{
Reduction of Salmonella Enteritidis contamination in broilers ${ }^{* *}$
}

\author{
LUIZ ANTONIO FACCENDA DE AVILA
}

\author{
Vladimir Pinheiro do Nascimento (Adviser - UFRGS)
}

Committee: Ricardo Alfredo Soncini (SADIA), Sérgio Luiz Vieira (UFRGS), Hamilton Luiz de Souza Moraes (UFRGS).

\begin{abstract}
Salmonellae that cause paratyphoid infection, mainly the Salmonella Enteritidis (SE), are among the main causes of foodborne diseases in humans, representing great loss for the poultry industry. The search for a unique and decisive control means has been frustrated due to the bacterial characteristics and the resulting infection. So, it becomes important the strategic use of a group of means that gradually reduce the infection pressure over the production system, taken to an increasing improvement of the contamination level of the final products offered to the consumers. The thesis goal is to offer to the poultry industry a group of feasible means to control the paratyphoid infection and, corollary, to produce safer food to human beings. Therefore, four studies were conducted. Three of them were dedicated to the increase of bird resistence to the SE infection and one to the reduction of Salmonella contamination level of the broilers at the pre slaughter period. The increase resistance of broiler breeders due to immunization with a SE bacterin was evaluated through an experiment. Three weeks after the challenge no differences were detected on the number of SE infected livers and ceca among the tested groups. This conclusion, although true under these conditions, needs further experiments under actual production systems to be corroborated. The maternal vaccination and the use of probiotics as means to increase the initial resistance of broiler chickens to SE infection were accessed through three experiments. The probiotics reduced the number of SE colony forming units (CFU) in the ceca up to $1.45 \log 10$. The greatest reduction occurred at Experiment III, indicating the importance of the administration of the probiotic being prior to the challenge. No effect of maternal vaccination on the number of ceca positive to SE or the number of SE CFU recovered from the ceca. The effect of spraying day old chickens with Salmonella Gallinarum strain 9R (SG-9R) on SE infection due to artificial challenge was accessed through four experiments. The application of SG-9R to day old chickens has a potential to help in the control of SE infection. In spite of this conclusion, further studies are needed to access the size of the effect, as well to determinate the probability of pathogenicity reversion of SG-9R. Three experiments were done to study the effect of administration of acidified water to the broilers at the pre slaughter period on the presence of SE in the crop. The use of acidified water starting 24 hours before the initial loading of broilers to the slaughter plant caused a reduction of $99 \%$ on the number of SE taken from the crop. This is not an ideal approach, since it does not avoid the presence of SE in the broiler and, also, does not warrant the production of food free of Salmonella. Although it can be a important tool to the contamination reduction of broiler flocks positive to Salmonella.
\end{abstract}

Key words: broilers, Salmonella Enteritidis, Salmonella contamination reduction, Poultry Paratyphoid. 